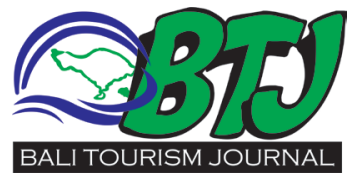

\section{COVID-19 canceled Omed-omedan Festival 2020 Local Elders: The Rite Would be Carry On!}

\author{
I Komang Bayu Segara ${ }^{1}$
}

${ }^{1}$ Staff of Dyatmika International School, Bali

Ik.bayusegara@gmail.com

Editor:

Ida Bagus Ngurah Tri Pramana

Received : 2020-07-28

Accepted : 2020-09-20

Published: 2020-10-05

\title{
ABSTRACT
}

The Government's decision to impose social restrictions threatened to cancel the Sesetan Heritage Omed-omedan Festival. Authority concerned that the crowd, both the Omed-omedan participants and spectators, might become a cluster for SARS-CoV-2 virus spread. However, to cancel the Omed-omedan might be challenging compared to cancel the $0 \mathrm{goh}$-ogoh parade on the night before Nyepi, Pengerupukan. Omed-omedan is a ritual in the Banjar Kaja Sesetan that is participated by local unmarried residents aged 17 to 30 . It is a sacred tradition that should avoid being neglected. The ritual has been developed into an annual tourism event that attracts local and foreign visitors to witness the sheer and joyous festival. However, covid-19 pandemic threatened to cancel the Sesetan Heritage 0med-omedan Festival in 2020. after being discussed by the Sesetan village leaders, it was decided that the Omed-omedan would be held without any accompanying festival such as an entertainment stage, cultural parade, flea market or even grand opening ceremony to control the crowd. The participant of the 0med-omedan also reduced to only three pairs of adolescents, with strict health protocol. Nevertheless, traditional village leaders of Sesetan also pleaded to the public to reconsider their plan to visit the old tradition, especially for the year 2020.

Keyword: The Sesetan Heritage Omed-omedan Festival, COVID-19, Banjar kaja, Sesetan

Cite This Article: Segara, I.K.B. 2020. COVID-19 canceled Omed-omedan Festival 2020 Local Elders: The Rite Would be Carry On!. Bali Tourism Journal (BTJ) 2020, 4(2): 40-43. D0I : 10.36675/btj.v4i2.47

\section{BACKGROUND}

The Government's decision to impose social restrictions threatened to cancel the Sesetan Heritage Omed-omedan Festival. Authority concerned the crowd; both the Omed-omedan participants and spectators might become a cluster for SARS$\mathrm{CoV}-2$ virus spread. However, to cancel the Omedomedan might be challenging compared to cancel the Ogoh-ogoh parade on the night before Nyepi, Pengerupukan. Omed-omedan is an annually-held ritual after the Balinese Hindu society in Banjar Kaja, Sesetan commemorates Saka Calendar New Year, Nyepi. The rite has a full of religious, historical background. Its sacred value is strongly related to the God who resides in Pererepan temple, Banjar Kaja. The unique tradition is classified as Purwa Dresta, a religious custom to ask for welfare for the community. ${ }^{1}$ According to the Banjar Kaja's elders, there was no written source related to the ritual history, yet the myth said the ritual had been held for approximately hundreds of years. Tale from one generation to another generation told that the Omed-omedan was a King's decree, which was mandatory to be carried out by the local community. The king was gravely ill until he mysteriously cured of his sickness after watching the Omed-omedan commotion.

\section{FROM RITUAL TO TOURISM FESTIVAL}

On Ngembak Geni, a day after Balinese Hindu celebrates Nyepi day, unmarried resident of Banjar Kaja, Sesetan with age between 17 to 30 years old gather in the village hall to participate in the Omed-omedan ritual. They realized the rite is not only a mere custom but their distinctive identity. Communication at the family and peer-level plays an essential role in providing knowledge to the younger generation of Banjar Kaja about the importance of carrying out the Omed-omedan tradition. ${ }^{2}$ The ceremony participants consisted of forty men and sixty women. When more people attend the Omed-omedan, the rest would be reserved for the next stage. It begins with a group praying at a local temple to ask for salvation. The participants would be divided into two groups, male and female. Later, each group would be asked to take positions facing each other on the main village road. An elder is assigned as a referee to start the ceremony. When the signal is given, the two groups will start to stand face to face and pull one of their members to the front. Randomly, one male and one female participant would be pulled into the middle of the crowd and forced to embrace each other. The officials would spray water on the couple until they are thoroughly soaked, which means the couple may be separated. Then, the ritual repeats itself, where the crowd of participants would continue 


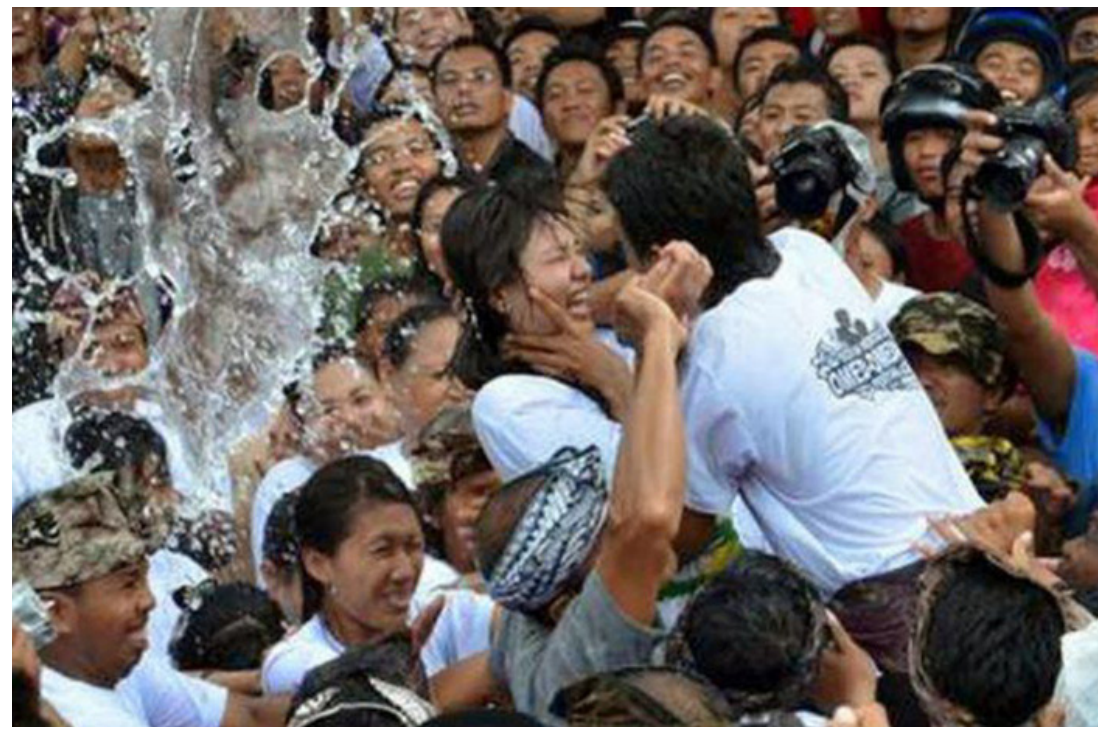

Figure 1. Randomly, one male and one female participant will be pulled into the middle of the crowd and forced to embrace each other. The officials would spray water on the couple until they are thoroughly soaked, which means the couple may be separated. ${ }^{3}$

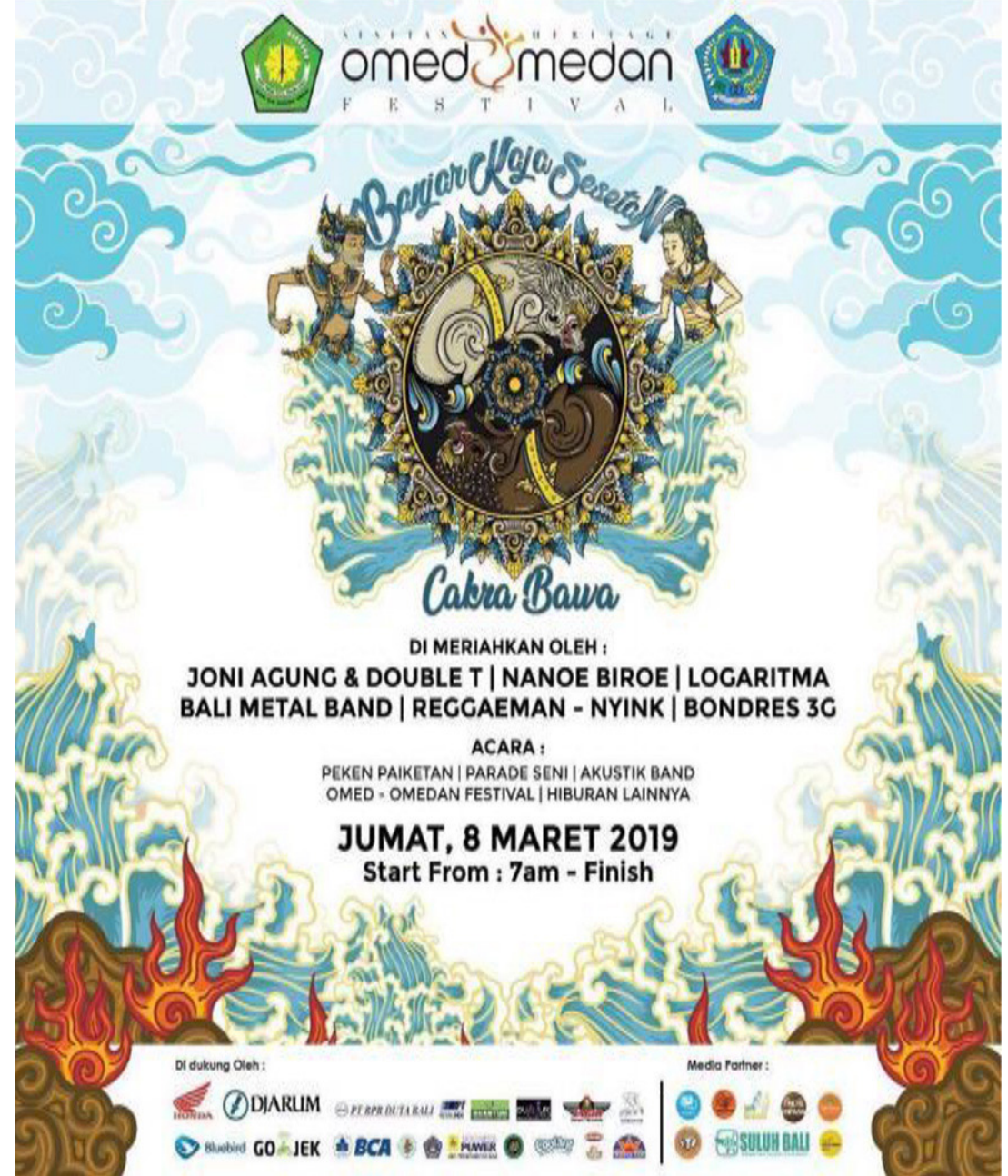

Figure 2. Promotion Banner of The Sesetan Heritage Omed-Omedan Festival in $2019^{9}$ to randomly pick a male and female to meet in the crowd. The ceremony usually is carried out until 17.00 local time.

According to local community leaders, the Banjar Kaja residents have been held this ritual since the $17^{\text {th }}$ century. However, at some point, the ritual was abolished for decades. It was said that, suddenly, two wild boars mysteriously appeared in the middle of the village. They fiercely mauled and wounded each other until completely covered in blood. The community believed that forest animals' appearance in the middle of the residential area was a bad omen, distress. The village was considered Panes, emitting a similar wilderness aura, and no longer serve as a place for humans to live. Should it left unchecked, the area would be slowly devoured by the demons and evil spirits. ${ }^{4}$ Likewise, in the Banjar Kaja community, they thought the omen resulted from the Omed-omedan absence for decades. They speculated if its first sacrifices were a couple of boars; what if the next victim would target humans?. Driven by the fear, the village elder hastily summoned an emergency meeting and pleaded to their youngsters to resume the forgotten ritual.

Eventually, the tradition's distinctive feature sparked interest from other communities to witness. Thus, since 2009 the activity had been promoted as an annual tourism event entitled the Sesetan Heritage Omed-omedan Festival. Denpasar Municipality Government provided various supports and assistance to promote the festival. Many improvements were made, such as infrastructure improvement, guidance and tourist areas management training presented by the cultural and tourism offices to escalate the festival to the international level. Besides, Banjar Kaja Sesetan is assigned as the official event organizer. ${ }^{5}$

\section{GOVERNMENT ANNOUNCEMENT TO RESTRICT CROWDS}

After the ministry of health announced health protocol guidance through circulated letter SE HK.0201 / MENKES / 202/2020 concerning SelfIsolation Protocol in Handling COVID-19, some notable events such as the Ogoh-ogoh parade and Bali Art Festival experienced bitter cancelation. Including the Omed-omedan might not possibly be held in 2020. However, on Wednesday, 18 March 2020, the head of the traditional division of Banjar Kaja Sesetan, I Made Sudama argued, Omedomedan would be performed on the day after Nyepi. His party supported Bali Governor's appeal to forbid crowd restriction entirely. Nevertheless, they insisted on carrying out the Omed-omedan tradition. ${ }^{6} \mathrm{He}$ emphasized the rites would be held 


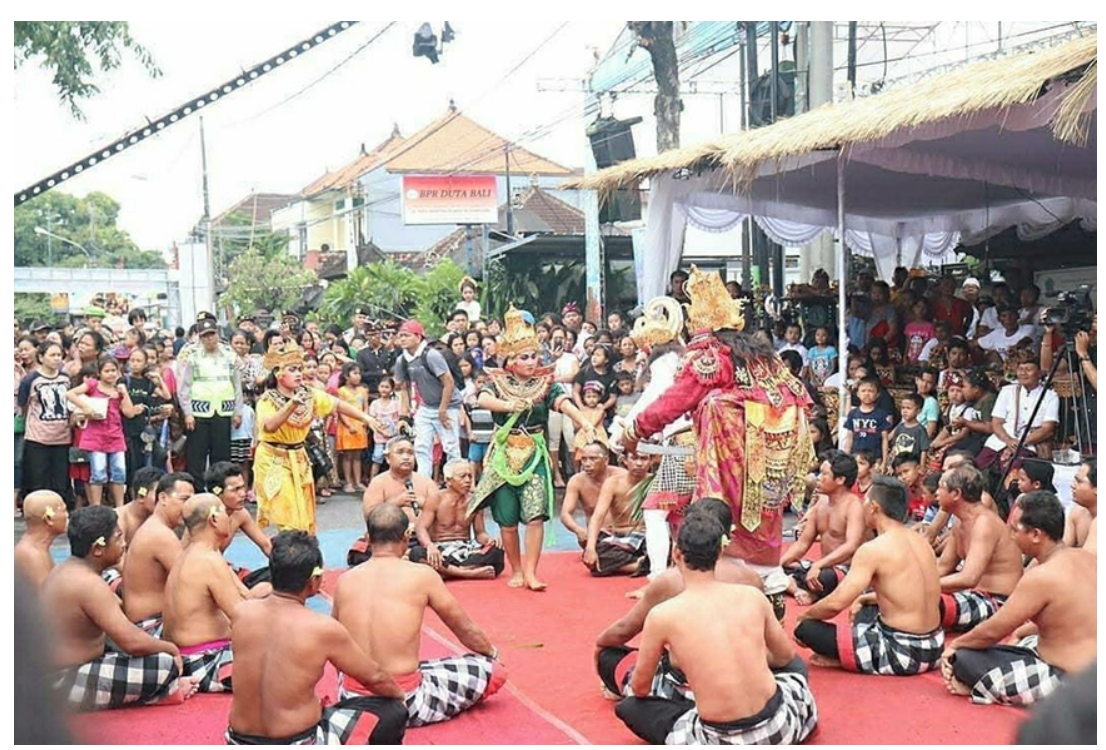

Figure 3. Commonly, the Sesetan Heritage Omed-omedan Festival enlivened by various activities such as grand opening ceremony, flea market, cultural parades, entertainment stages, and the Omed-omedan for the non-Banjar Kaja community. ${ }^{12}$

without any festival. The decision was made after community leaders conducted an urgent meeting to ensure ritual continuity. Besides, the Government's letter did not urge to prohibit any event; It requests the event organizer to restrict people gathering in such a place. Thus, to cancel the Sesetan Heritage Omed-omedan Festival 2020 would be a wise decision. It would significantly reduce the crowd number on the due day and did not violate the Government's order. ${ }^{7,8}$

Sudama explained that his party could not cancel the sacred tradition. He insisted an oddly unexplainable phenomenon had proven that it occurred when they neglected the custom. Such concern became a strong reason why the locals refused to cancel their annual tradition. They feared a poor decision could lead to a catastrophic result. Therefore, the Grand meeting with village leaders of Sesetan strictly decided to held Omed-omedan without a festival. They argued the festival only serves as a supporting event, not the main event. Commonly, the Sesetan Heritage Omed-omedan Festival enlivened by various activities such as grand opening ceremony, flea market, cultural parades, entertainment stages, and the Omed-omedan for the non-Banjar Kaja community. ${ }^{10}$

As for tradition, the village leaders also considered reducing the number of youngsters' participation. Only for this urgent occasion, it would be only participated by three pairs of teenagers. In contrast, typically, it can be more than a hundred people since Banjar Kaja residents reached 500 households. If every adolescent in the households participated, there would be 500 Omedomedan participants, although it was rarely to occur. Meanwhile, community leaders would hold the Guru Piduka ceremony, a ritual to apologize to God for the conscious and unconscious mistakes they might have made. Further, the Omed-omedan organizer also agreed to negate any promotion or publication related to the ritual in $2020 .^{11}$

\section{A PLEAD TO SOCIETY}

the Sesetan Traditional Village staff represented by their Secretary, Dudik Mahendra, appealed to the broader public and tourists to cancel their plan to visit the limited Omed-omedan ritual conducted on Thursday, 26 March 2020. Similar actions by Indonesia Hindu Council (PHDI) Bali office, Traditional Village Council of Bali Province (MDA), and Bali Provincial Government had made official letters regarding COVID-19 protocol for ceremony and ritual. Residents who were sick are unallowed to participate in any Nyepi procession activities, from Melasti, Tawur Agung, the Ogohogoh parades, including Banjar Kajas annual rite, Omed-omedan. Dudik added the 2020 ritual would be significantly simplified. There would be no flea market Peken Lais Meseluk, no entertainment stage, including any grand opening. It is expected that the decision would minimize the crowd from neighborhood areas.

On occasion, he also explained misconceptions in society about the ritual. Some argued that Omedomedan is inappropriate to be shown in public. He explained that Omed-omedan is a representation of the Banjar Kaja residents' intimacy and spirit of brotherhood. Such tradition is believed to create a harmonious atmosphere in the area, in contrast to the boar bloodshed event. Besides, the tale of a sick king who became suddenly healthy after witnessing the Omed-omedan reinforced the local belief that the custom can ward off plagues and diseases. The Omed-omedan is not a 'public kissing' tradition. Instead, Omed-omedan means mutual attraction between young men and women. However, as time goes by, he admitted, some people used the event as an opportunity as a moment to express their lust through inappropriate actions. Academic research in 2018 found the Banjar Kaja adolescent's interest, primarily female participants of Omed-omedan , can be classified into two motives; they are intrinsic and extrinsic motivation. Intrinsic motivation comprises six aspects: curiosity, pleasure, belief, principle, pride, and new information. While Extrinsic motivation consists of seven aspects, namely facilities, obligations, invitations, partner roles, benefits, spare time activity, and social pressure. ${ }^{13}$ 
Furthermore, the traditional village leader of Sesetan instructed his staff to socialize several changes in Omed-omedan ritual 2020 and health protocol to counter COVID-19 spread on location. It is crucial to ensure the message is well delivered since it has been ten years; the Sesetan heritage Omed-omedan Festival always invites thousands of people flocked to the Sesetan area. Some actions such as Independent disinfectant spraying around the area, hand sanitizer, temperature checking protocol, and taskforces availability were attentively conducted and checked. The village secretary hoped that non-Sesetan residents would prefer to stay at home, avoid to watch the ritual in 2020 for the common good. ${ }^{14,15}$

\section{CONCLUSION}

Omed-omedan is a ritual in the Banjar Kaja Sesetan. The rite is participated by local unmarried residents aged 17 to 30 . It is considered to be a sacred tradition that should avoid being neglected. The ritual has been developed into an annual tourism event that attracts local and foreign visitors to witness the sheer and joyous festival. However, covid-19 pandemic threatened to cancel the Sesetan Heritage Omedomedan Festival in 2020. after being discussed by the Sesetan village leaders, it was decided that the Omed-omedan would be held without any accompanying festival such as an entertainment stage, cultural parade, flea market or even grand opening ceremony to control the crowd flocking. The participant of the Omed-omedan also reduced to only three pairs of adolescents, with strict health protocol. Nevertheless, traditional village leaders of Sesetan also pleaded to the public to reconsider their schedule visiting the Omed-omedan tradition, especially for the year 2020 .

\section{REFERENCES:}

1. Artiningsih NW. INTERNALISASI NILAI SAKRAL DALAM TRADISI OMED-OMEDAN DI BANJAR KAJA KELURAHAN SESETAN KOTA DENPASAR. Purwadita: Jurnal Agama dan Budaya. 2019 Aug 26;1(2):1-7.

2. Merta NM, Suryawati IG, Pradipta AD. Proses Komunikasi Masyarakat Banjar Kaja, Sesetan, Denpasar Selatan, Bali dalam Mewariskan Nilai Tradisi Omed-omedan.

3. Image Collection of Disparda Prov Bali' Omed-omedan' Official Site of Disparda Prov. Bali. 2020. Available at URL: https://disparda.baliprov.go.id/omed-omedan-2/2020/05/.
4. Harsananda H, Widyawati AA. Karang Paumahan Perspektif Ekologi Hindu. Sphatika: Jurnal Teologi. 2020 Jul 4;10(2):132-9.

5. Mahardika I, Roy WD. Festival heritage Omed-omedan sebagai daya tarik wisata di Sesetan, Denpasar. Jumpa Jurnal Master Pariwisata. 2019;1(2):117-33.

6. Anonymous. Banjar Kaja, Sesetan Tetap Gelar Omedomedan. Nusa Bali. 2020. Available at URL: https://www. nusabali.com/berita/70587/banjar-kaja-Sesetan-tetapgelar-omed-omedan.

7. D Divianta. COVID-19, Festival Omed-Omedan di Bali Ditiadakan. Liputan6[dot]com. 2020. Available at URL: https://www.liputan6.com/regional/read/4210627/covid19-festival-omed-omedan-di-bali-ditiadakan.

8. Anonymous. Dampak Corona di Bali: Festival Omedomedan Batal, Ritual Tetap Berlangsung . Kanal Bali. 2020. Available at URL: https://kumparan.com/kanalbali/ dampak-corona-di-bali-festival-omed-omedan-batalritual-tetap-berlangsung-1t6GaHJQtRm/full.

9. Image Collection of Denpasar City' SESETAN HERITAGE OMED OMEDAN FESTIVAL 2019'. Official Site of Denpasar City Official Site. 2019. Available at URL: https:// www.denpasarkota.go.id/event/baca/1028.

10. A Putera. Omed-omedan Tetap Berlangsung, Hanya ini Ditiadakan. Bali Post. 2020. Available at URL:https://www. balipost.com/news/2020/03/18/110297/Omed-omedanTetapBerlangsung,Hanya-Ini...html.

11. Anonymous. Omed-omedan Hanya Libatkan Tiga Pasang Sekaa Teruna. Nusa Bali. 2020. Available at URL: https:// www.nusabali.com/berita/70684/omed-omedan-hanyalibat-tiga-pasang-sekaa-teruna.

12. Image Collection of Sekilas Bali 'Pembukaan Festival Omed-Omedan'. Sekilasbali[dot]com. 2019. Available at URL: https://www.facebook.com/sekilasbalicom/posts/ pembukaan-festival-omed-omedanjumat-080319-sedangberlangsung-pembukaan-festival/2577636348917674/.

13. Dwijayanthi IA, Tobing DH. FACTORS AFFECTING YOUTH PARTICIPATION MOTIVATION IN THE OMED-OMEDAN TRADITION IN BANJAR KAJA, KELURAHAN SESETAN, DENPASAR. Journal of Psychology Udayana. 2018; 5 (1): 173-88.

14. AAU Ermalia. Prajuru Desa Adat Sesetan Imbau Jangan Datang Menonton Omed-omedan. IDN times Bali. 2020. Available at URL: https://bali.idntimes.com/news/bali/ ayu-afria-ulita-ermalia/prajuru-desa-adat-Sesetan-imbaujangan-datang-menonton-omed-omedan/4.

15. Anonymous. Ritual Omed-omedan Hanya Tiga Pasangan, Diawali Guru Piduka. Bali Express. 2020. Available at URL: https://baliexpress.jawapos.com/read/2020/03/19/184689/ ritual-omed-omedan-hanya-tiga-pasangan-diawali-gurupiduka.

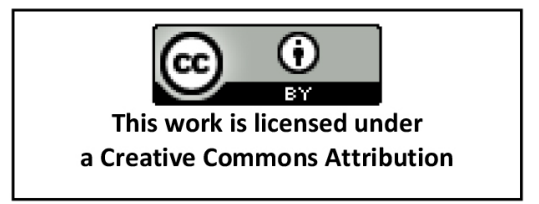

